\title{
Chronic Hemolytic Anemia due to Cold Agglutinins
}

\section{THE ROLE OF C' IN RED CELL DESTRUCTION}

\author{
Robert S. Evans, Elizabeth Turner, Margaret Bingham, and \\ RichaRd WoOdS \\ From the Medical Service of the Veterans Administration Hospital and the \\ Department of Medicine of the University of Washington School of \\ Medicine, Seattle, Washington 98108
}

A BSTRACT The sera of four patients with chronic hemolytic anemia due to cold agglutinins deposited $\mathrm{C}^{\prime}$ globulins on normal red cells at $37^{\circ} \mathrm{C}$. The circulating cells of the patients were heavily coated with $\mathrm{C}^{\prime}$ complex and were relatively resistant to $C^{\prime}$ hemolysis by cold agglutinin. Such red cells were removed from the patients' circulation at an exponential rate with ${ }^{51} \mathrm{Cr} \mathrm{t}_{1}$ that varied from 7 to 19 days. Normal red cells were removed rapidly by hepatic sequestration during the first hours in the patients' circulation. Thereafter, a slower rate of abnormal destruction occurred which was associated with the accumulation of $\mathrm{C}^{\prime}$ complexes on the red cell and the development of resistance to $C^{\prime}$ hemolysis by cold agglutinin. Normal red cells coated with sufficient $\mathrm{C}^{\prime}$ complex by action of cold agglutinins in vitro to produce resistance to $C^{\prime}$ hemolysis by cold agglutinins demonstrated varying degrees of improved survival during the first hours in the circulation of three of the patients.

The levels of serum $C^{\prime}$ were reduced in all four patients with chronic hemolytic anemia due to cold agglutinins. Transfusion of large volumes of normal red cells into two patients further reduced serum $\mathrm{C}^{\prime} .{ }^{31} \mathrm{Cr}$-labeled normal red cells survived longer after red cell transfusions than before, because of less rapid destruction during the first hours in the circulation. The reduction in serum $\mathrm{C}^{\prime}$ levels appeared responsible for the improved survival.

Received for publication 13 March 1967 and in revised form 4 December 1967.
In subjects without cold agglutinins, the presence of the spleen decreased the survival of red cells from a patient who had previously undergone splenectomy. Splenic removal also predominated in the reduced survival of autologous red cells in one patient. Neither hepatic nor splenic mechanisms predominated in removing autologous $\mathrm{C}^{\prime}$-coated cells in the other two patients.

\section{INTRODUCTION}

The hemolytic anemia associated with high titers of anti-I cold agglutinins is sometimes intermittent, with acute episodes of hemolysis after exposure to low temperatures. In the majority of our patients abnormal blood destruction has been chronic and independent of reduction in body temperature. It is probable that the episodes of hemoglobinuria that follow chilling in some patients are due to complement $\left(\mathrm{C}^{\prime}\right)$ hemolysis by these macroglobulin antibodies which have hemolytic as well as agglutinating properties (1). The patients with the chronic form of hemolytic anemia which we have studied have not manifested hemoglobinuria when exposed to low temperatures, despite the occurrence of acrocyanosis secondary to intravascular agglutination. There are two features of the disease in such patients which appear to prevent acute hemolysis. Serum $C^{\prime}$ values are usually low and the circulating red cells are abnormally resistant to $\mathrm{C}^{\prime}$ hemolysis in vitro by anti-I cold agglutinins. $^{1}$

1 The traditional term "cold agglutinins" will be retained in denoting these red cell antibodies in this report. 
In a preceding report we have presented evidence that accumulation of $\mathrm{C}^{\prime}$ globulins by the red cell resulting from repeated transient reactions with cold agglutinin at body temperature is the principal cause of the resistance of the patients' red cells to $C^{\prime}$ hemolysis in the chronic form of the disease (2). Data presented here indicate that incomplete $C^{\prime}$ complexes, which accumulate on the circulating red cells at normal body temperatures, protect red cells from rapid destruction by $\mathrm{C}^{\prime}$ and cold agglutinin, but lead to a more gradual removal in which splenic sequestration may predominate.

\section{METHODS}

\section{Patient material}

Studies of four patients with chronic hemolytic anemia associated with cold agglutinins with anti-I specificity are reported. The basic hematologic and serologic data appear in Table I.

Case 1. E. M., a 60-yr-old male with high titers of cold agglutinin, has been reported on previously (3). Splenectomy in August 1962 was followed by improvement in hematocrit for 18 months. The patient's red cells, which had exhibited relatively normal morphology and hypotonic fragility before splenectomy, developed spherocytosis and a marked increase in hypotonic fragility. After this period of improvement a gradual fall in hematocrit began. $1 \mathrm{yr}$ later, after prolonged exposure to cold, he was readmitted with gangrene of both lower extremities. Studies reported here were carried out after the onset of relapse, before and after recovery from bilateral below-the-knee amputations.

Case 2. A. J., an $81 \mathrm{yr}$ old woman, had noted acrocyanosis for 3 yr but never observed change in color of the urine after chilling. Her symptoms remained much the same during the $3 \mathrm{yr}$ before the study but her cold agglutinin titer had increased from $1: 32,000$ to $1: 200,000$. Physical examination was without significant abnormalities.

Case 3. O. A., a $76 \mathrm{yr}$ old man, noted cyanosis and pain in his fingers and toes during exposure to cold in 1955. These symptoms increased gradually until, in 1964, the hematocrit was $34 \%$, reticulocytes were $4 \%$, the serum bilirubin was elevated, and cold agglutinins were present in high titer. The patient then received $10 \mathrm{mg}$ of Chlorambucil daily for 4 months. This was discontinued 1 month before our observations. The liver was not enlarged and the spleen was not palpable.

Case 4. B. C., a $73 \mathrm{yr}$ old man who had been losing weight for $1 \mathrm{yr}$, developed symptoms of gall bladder disease and underwent cholecystectomy. At that time he was anemic and was found to have cold agglutinins. There was no adenopathy and liver and spleen were not palpable.

The first three patients had high titers of cold agglutinins associated with acrocyanosis. The fourth had lower levels of cold agglutinins and had not noted acrocyanosis. The cold agglutinins of all four patients produced $\mathrm{C}^{\prime}$ hemolysis of normal cells at $30^{\circ} \mathrm{C}$; the cold agglutinins of two (E. M. and A. J.) were hemolytic at $37^{\circ} \mathrm{C}$ within a $\mathrm{pH}$ range of 7.2-7.4. The sera of all four deposited $\mathrm{C}^{\prime}$ globulins on normal red cells at $37^{\circ} \mathrm{C}$ even though $\mathrm{C}^{\prime}$ hemolysis was not produced at this temperature by the sera of two (O. A. and B. C.).

The red cells of all four patients washed at $37^{\circ} \mathrm{C}$ were agglutinated by antiglobulin serum with anti- $\beta_{1 \mathrm{c}}\left(\mathrm{C}^{\prime} 3\right)$ and anti- $\beta_{1}\left(C^{\prime} 4\right)$ activity $(2,4,5)$. Agglutination was not produced by antisera with anti- $\gamma \mathrm{G}$ and anti- $\gamma \mathrm{M}$ activity. The adsorption of ${ }^{181} \mathrm{I}$-labeled anti- $\beta$-globulin serum was always three to four times that adsorbed by normal red cells and within the same range as normal red cells that had been reacted with cold agglutinin and $\mathrm{C}^{\prime}$ so as to produce accumulation of $\mathrm{C}^{\prime}$ globulins (2). The patients' red cells were resistant to $\mathrm{C}^{\prime}$ hemolysis by cold agglutinins at $25^{\circ} \mathrm{C}$ within the $\mathrm{pH}$ range of $7.2-7.4$, and although slight $\mathrm{C}^{\prime}$ hemolysis occurred at $\mathrm{pH} 6.8$, the

TABLE I

Summary Data from Patients with Chronic Hemolytic Anemia and Cold Agglutinins

\begin{tabular}{|c|c|c|c|c|c|c|c|}
\hline Patient & Hct. & Retic. & $\begin{array}{l}\text { Titer cold } \\
\text { agglutinin }\end{array}$ & $\begin{array}{c}t_{\frac{1}{3}} \text { sur- } \\
\text { vival of } \\
\text { patients } \\
{ }^{1} \mathrm{Cr} \text { cells }\end{array}$ & $\begin{array}{c}\mathrm{C}^{\prime} \\
\text { levels }\end{array}$ & $\begin{array}{l}\mathrm{C}^{\prime} \text { hemolysis } \\
\text { of pts' cells } \\
\text { by cold ag- } \\
\text { glutinin of } \\
\text { E. M.* at } \\
\text { pH } 7.2,25^{\circ} \mathrm{C}\end{array}$ & $\begin{array}{l}\text { Uptake } 131 \text { I- } \\
\text { labeled anti- } \beta \text { - } \\
\text { globulin } \\
\text { serum } \ddagger\end{array}$ \\
\hline & & $\%$ & & & $C^{\prime} H 5 O U \S$ & $\%$ & \\
\hline Case 1 E. M. & 27 & 3 & $1: 500,000$ & 20 & 35 & 0 & $4.0 \times$ \\
\hline Case 2 A. J. & 26 & 3 & $1: 200,000$ & 16 & 40 & 0 & $4.0 \times$ \\
\hline Case 3 O. A. & 37 & 4 & $1: 32,000$ & 11 & 70 & 0 & $3.6 \times$ \\
\hline Case 4 B. C. & 24 & 5 & $1: 512$ & 7 & 34 & 0 & $4.0 \times$ \\
\hline
\end{tabular}

* Normal cells have shown $9-52 \% \mathrm{C}^{\prime}$ hemolysis under the same conditions.

$\ddagger$ Recorded as ${ }^{131}$ I-labeled anti- $\beta$-globulin activity adsorbed by patient's cells compared to the activity adsorbed by normal cells.

§ Normal levels, 85-125 C'H50 units. 
percentage hemolysis was always less than the limits of variation shown by normal cells.

The subjects who volunteered for the studies of survival of ${ }^{51} \mathrm{Cr}$-labeled cells were normal individuals or patients with any one of a variety of disorders. None had evidence of blood loss or hemolytic activity. Most asplenic subjects had received previous transfusions. Isoantibodies for red cells could not be demonstrated by in vitro tests. Subjects with normal splenic circulation had not been transfused previously.

\section{Experimental methods}

The techniques employed in the isolation and study of radioiodinated cold agglutinin have been described elsewhere (1).

Coating of normal cells with $C^{\prime}$ globulins. The methods used to accumulate $C^{\prime}$ complex on normal cells by action of cold agglutinin are described in a report on the in vitro studies of the resistance of such cells to $C^{\prime}$ hemolysis by cold agglutinins (2). The same technique has been employed under sterile conditions to coat normal cells with $C^{\prime}$ complex for in vivo survival studies. In later experiments, it was demonstrated that the plasma of $\mathrm{E}$. $\mathrm{M}$. collected in acid citrate dextrose (ACD) solution in the proportion of 10 parts whole blood to 1 part ACD could be used as the source of cold agglutinin with production of only $1-2 \% \mathrm{C}^{\prime}$ hemolysis during the coating of normal cells. The plasma was mixed with 3 volumes of normal serum, and 1 volume of normal cells was suspended in an equal volume of the serum plasma mixture. The reagents were mixed at $37^{\circ} \mathrm{C}$ and then cooled to $25^{\circ} \mathrm{C}$. The temperature was again raised to $37^{\circ} \mathrm{C}$. Alternation of temperature was accomplished five times in $30 \mathrm{~min}$. At the end of $30 \mathrm{~min}$, the cells were sedimented at $37^{\circ} \mathrm{C}$ and the mixture of plasma and normal serum was replaced. This procedure was repeated for $3 \mathrm{hr}$. The degree of hemolysis was measured by comparing the amount of hemoglobin in the supernatant fluid with $100 \%$ hemolysis of an equal volume of red cells. The coated red cells, normal red cells, and the red cells of the patients were tested for susceptibility to $C^{\prime}$ hemolysis by cold agglutinin as described below. Red cells coated with $C^{\prime}$ complex in vitro by action of cold agglutinin and normal serum will be referred to as $C^{\prime} 1423$ cells though it is recognized that other fractions of $C^{\prime}$ globulins may also be present (2).

Anti-B-globulin serum. The production and testing of antisera for human $\mathrm{C}^{\prime}$ globulins, as well as the radioiodination of the antisera and its use in measuring $C^{\prime}$ globulins on normal cells, have been described elsewhere (2). The adsorption of radioiodinated anti- $\beta$-globulin serum by red cells of patients is compared with the adsorption of the antiserum by normal cells and expressed as the ratio of radioactivity of patients' cells to normal cells. Red cells from patients with hemolytic disorders not associated with immunological abnormalities adsorbed the same amount of ${ }^{181} \mathrm{I}$ activity as normal red cells.

$C^{\prime}$ hemolysis by cold agglutinin. $0.1 \mathrm{ml}$ of cells was suspended in $1 \mathrm{ml}$ of a mixture of 1 part patient's serum containing cold agglutinins and 3 parts normal serum.
The sera had been adjusted to $\mathrm{pH} 7.2$ or 6.8 by addition of mineral acid. The cell serum suspension was mixed at $37^{\circ} \mathrm{C}$ and then incubated at $25^{\circ} \mathrm{C}$, or at a higher temperature if so designated. After $30 \mathrm{~min}$ the hemoglobin concentration was compared to that produced by $100 \%$ osmotic hemolysis of an aliquot of the same suspension.

When ${ }^{51} \mathrm{Cr}$-labeled cells were present, the percentage hemolysis of these cells was determined by comparing the ${ }^{51} \mathrm{Cr}$ counts in the supernatant hemolysate with the total ${ }^{51} \mathrm{Cr}$ counts of the specimen.

Titration of serum complement. The titration of human complement was performed by the method of Ecker, Pillemer, and Seifter (6).

${ }^{5} \mathrm{Cr}$ labeling of normal and $C^{\prime}$-coated red cells. $10 \mathrm{ml}$ of whole blood was collected with $2.0 \mathrm{ml}$ of ACD solution which served as anticoagulant and a medium to hasten the labeling of red cells by ${ }^{51} \mathrm{Cr}$ (7). $100 \mu \mathrm{c}$ of ${ }^{51} \mathrm{Cr}$ as $\mathrm{Na}_{2} \mathrm{CrO}$, was added to the blood with constant agitation. The final concentration of the chromium salt was less than $2.0 \mu \mathrm{g} / \mathrm{ml}$ of blood (8). The suspension was maintained at $37^{\circ} \mathrm{C}$ for $30 \mathrm{~min}$ before the red cells were sedimented and the supernatant removed. The cells were then washed three times at $37^{\circ} \mathrm{C}$ in sterile isotonic saline and resuspended to the original volume of whole blood. Measurement of cells for injection was done with a calibrated syringe. The first venous sample was removed from the opposite arm $5 \mathrm{~min}$ after completion of injection and at designated intervals thereafter. Dried heparin or EDTA was used as an anticoagulant for the specimens. Duplicate 2-ml samples were pipetted into disposable plastic tubes and the radioactivity was determined in a Packard well-type gamma counter. The radioactivity of the sample removed at $5 \mathrm{~min}$ was used as the reference point and the percentage values of subsequent specimens were plotted against time on semilogarithmic scale. Plasma concentrations of ${ }^{51} \mathrm{Cr}$ were determined after injection of some cell suspensions.

Body scanning was performed with a directional scintillation counter (Packard auto-gamma spectrometer) with the patient supine. The counts per minute over the liver, spleen, and precordium were expressed as ratios of liver to precordium counts and spleen to precordium counts according to the method of Jandl, Greenberg, Yonemoto, and Castle (9).

\section{RESULTS}

Survival of the patients' red cells in the autologous circulation and in the circulation of normal and asplenic subjects. The red cells of $\mathrm{E}$. M. (case 1) labeled with ${ }^{51} \mathrm{Cr}$ and washed at $37^{\circ} \mathrm{C}$ were observed for survival in vivo in four separate experiments. Survival of aliquots of labeled cells in the patient and other subjects without spleens was compared with survival in normal subjects. The results of these studies are summarized in Table II. The $t_{\frac{1}{2}}$ of survival was always shorter in the normal subject than in the patient 
TABLE II

$t_{1}$ of Survival, of ${ }^{51} \mathrm{Cr}$-Labeled Cells of E. M. in the Autologous Circulation and in the Circulation of Subjects with and without Normal Splenic Circulation

\begin{tabular}{cccc}
\hline \multicolumn{4}{c}{ ts of survival } \\
\hline Expt. & $\begin{array}{c}\text { Patient } \\
\text { with } \\
\text { spleen } \\
\text { absent }\end{array}$ & $\begin{array}{c}\text { Asplenic } \\
\text { subjects }\end{array}$ & $\begin{array}{c}\text { Normal } \\
\text { subjects }\end{array}$ \\
\hline & & days & \\
2 & 20 & 13 & 5 \\
3 & - & 17 & 3 \\
$4^{*}$ & 19 & - & 7 \\
\hline
\end{tabular}

* This survival study was started after the patient received $2 \mathrm{U}$ of red cells.

or asplenic subject. Surface counting in the four normal subjects demonstrated that the spleen was the principal site of sequestration of the ${ }^{51} \mathrm{Cr}$ labeled cells in the two with the shortest survival. Splenic localization was not demonstrated in the other two. It should be noted that the red cells of E. M. were spherocytic and susceptible to hemolysis in hypotonic solution. This change in shape had appeared during the partial remission after splenectomy.

The red cells of A. J. (case 2) and B. C. (case 4) exhibited normal survival in both normal and asplenic subjects. The $t_{\frac{1}{2}}$ survival of autologous cells was 16 days for A. J. and 7 days for B. C. There was slight parallel increase in both spleenprecordium and liver-precordium ratios in A. J., whereas the spleen-precordium ratios increased significantly in B. C. Despite the relatively low titer of cold agglutinins in the latter patient, the $t_{\frac{1}{2}}$ of 7 days exceeded the rate of removal of autologous cells of any other patient in the series.

Survival in patients of normal red cells and normal red cells coated with $C^{\prime}$ complex in vitro. When ${ }^{51} \mathrm{Cr}$-labeled group O I-positive cells from a normal donor were given to E. M. (case 1) the rate of removal was rapid. About $50 \%$ of the red cells remaining in the circulation $5 \mathrm{~min}$ after injection was removed at the end of $1 \mathrm{hr}$. The rate of disappearance then diminished and the remaining cells were removed at an exponential rate with a $t_{1}$ of 12-14 days (Fig. 1). A week later, cells from this donor were coated with $\mathrm{C}^{\prime}$ globulins by incubation with cold agglutinin and whole serum. Approximately 7\% hemolysis had occurred during the $3 \mathrm{hr}$ of incubation. The residual cells were resistant to $\mathrm{C}^{\prime}$ hemolysis by cold agglutinins and showed a slight increase in hypotonic fragility. The survival of the $C^{\prime} 1423$ cells is compared with the survival of the normal cells and survival of autologous cells in Fig. 1.

After injection of the normal red cells $10 \%$ of the ${ }^{51} \mathrm{Cr}$ counts present in whole blood at $5 \mathrm{~min}$ was in the plasma as opposed to $1.5 \%$ with $\mathrm{C}^{\prime} 1423$ cells. Blood volume determinations based on the 5 -min ${ }^{51} \mathrm{Cr}$ counts of whole blood were 3200 and $3500 \mathrm{ml}$ for the normal and $\mathrm{C}^{\prime} 1423$ cells respectively. The higher plasma counts after the injection of normal red cells indicate that appreciable intravascular hemolysis occurred without clearance of the ${ }^{51} \mathrm{Cr}$, though some of the plasma counts may have been contributed by $\mathrm{C}^{\prime}$ hemolysis during collection before mixing with EDTA.

This experiment was repeated 7 months later when the hematological status was unchanged. $C^{\prime} 1423$-coated cells from the donor used in the previous experiment were administered before the normal cells. The survival curves of each were approximately the same as those shown in Fig. 1, indicating that the order of administering the normal and C'1423-coated red cells did not influence their survival.

Similar observations were made with normal

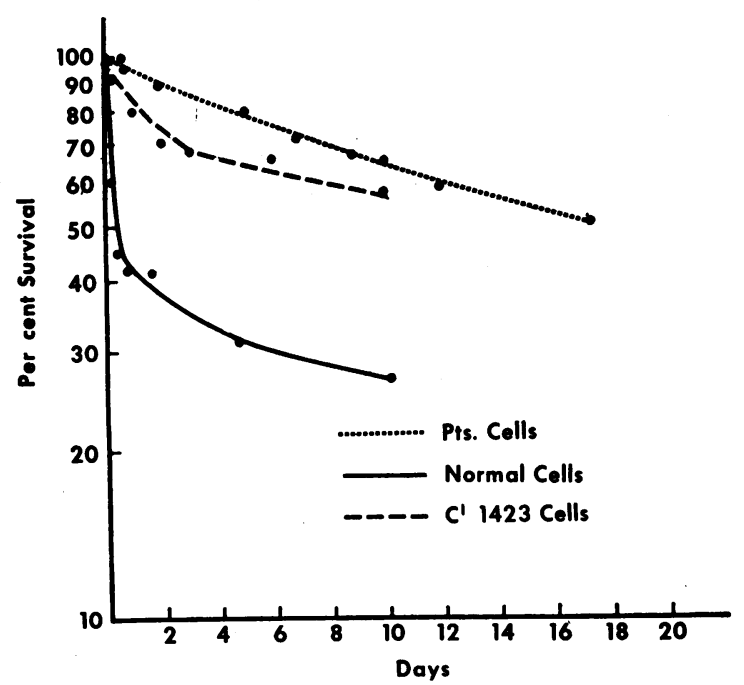

Figure 1 Survival of normal group O I-positive cells in E. M. and survival after the cells were coated with $C^{\prime} 1423$ complex through the action of cold agglutinin compared with survival of autologous cells. 


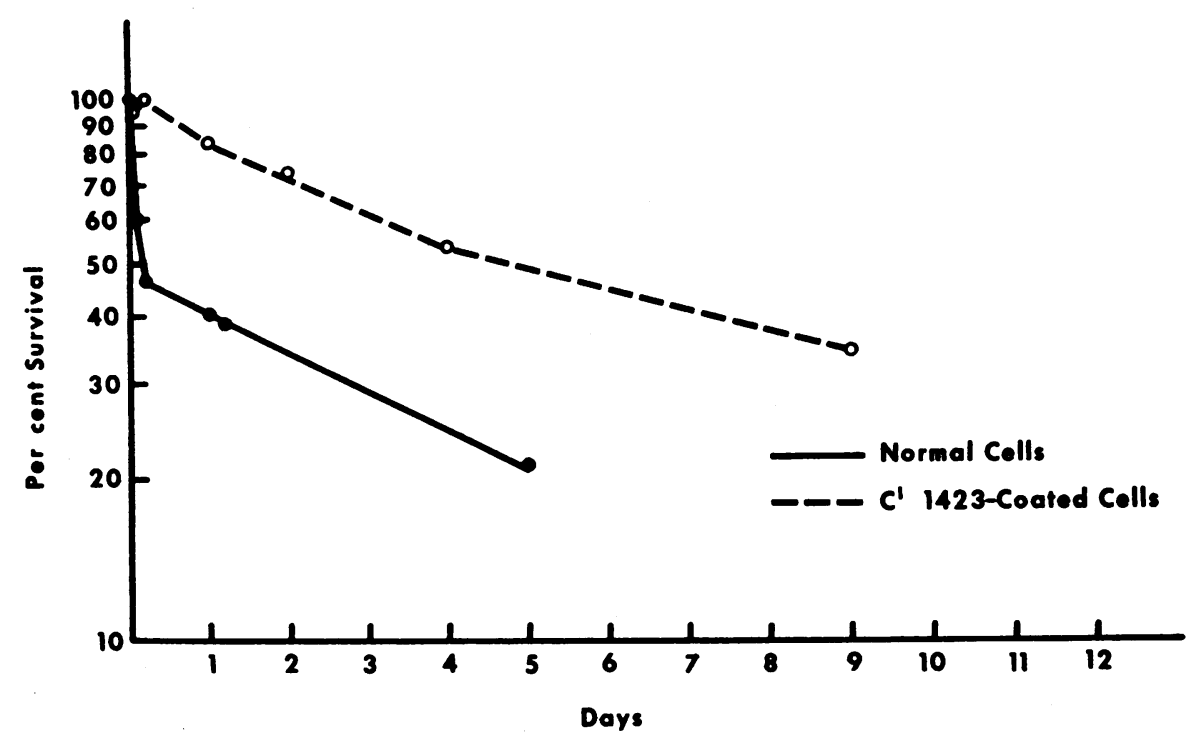

FIGURE 2 Survival of normal group O I-positive cells in A. J. and survival, of cells from the same donor after coating with $C^{\prime} 1423$ complex.

group O I-positive cells in patient A. J. (case 2). More than $50 \%$ of the normal cells was removed in $40 \mathrm{~min}$. Thereafter, the rate of removal was more gradual with a $t_{1}$ of about 5 days. 6 wk after this survival curve, cells from the same donor were coated with $C^{\prime}$ globulins by incubation with ACD plasma of E. M. and normal human serum. There was minimal hemolysis during preparation and the cells were demonstrated to be resistant to $\mathrm{C}^{\prime}$ hemolysis by cold agglutinin at $\mathrm{pH}$ 7.2. These $\mathrm{C}^{\prime} 1423$ cells did not undergo the initial period of rapid destruction since $100 \%$ of the counts present at $5 \mathrm{~min}$ was present at $3 \mathrm{hr}$ (Fig. 2). The rate of destruction then corresponded to the second, slower phase of destruction of the normal red cells with a $t_{1}$ survival of approximately 5 days. $6 \mathrm{wk}$ later, when the hematologic status of the patient was unchanged, ${ }^{51} \mathrm{Cr}$-labeled cells from the same donor were again injected without prior treatment with $\mathrm{C}^{\prime}$. The rate of destruction duplicated the first survival of the normal ${ }^{51} \mathrm{Cr}$-labeled cells. An increase in the liver-precordium ratio occurred during the rapid removal of normal cells, but did not occur during removal of the $C^{\prime} 1423$ cells.

When the normal red cells were given, approximately $10 \%$ of the ${ }^{51} \mathrm{Cr}$ counts present in whole blood was in the plasma at $5 \mathrm{~min}$ as opposed to $0.5 \%$ with the $C^{\prime} 1423$ cells. Blood volumes calculated from the 5 -min samples varied from 2400 to
$2800 \mathrm{ml}$ for this $40 \mathrm{~kg}$ woman. Measurements obtained with autologous red cells were within this range.

At a later date, the observations of red cell survival were repeated except that red cells coated with $\mathrm{C}^{\prime}$ globulins by the action of cold agglutinins of A. J. were given first. The $t_{\text {surival of the }}$ $C^{\prime} 1423$ cells was 4 days, whereas that of the normal red cells was between 1 and 2 days.

Additional observations of red cell survival in these patients were of interest. Red cells coated with $C^{\prime}$ complexes by the action of cold agglutinin and zymosan-adsorbed serum (R3) were removed from the circulation of $\mathrm{E}$. M. as rapidly as normal red cells even though they were resistant to $C^{\prime}$ hemolysis in vitro. Red cells coated with $\mathrm{C}^{\prime}$ globulins by incubation with cold agglutinin and onethird the amount of normal serum usually employed did acquire a coating of $\beta$-globulins but were not significantly more resistant than uncoated cells to $C^{\prime}$ hemolysis in vitro. These red cells were removed from the circulation of A. J. almost as rapidly as normal red cells with $32 \%$ removed in $1 \mathrm{hr}$ and a $\mathrm{t}_{1}$ of survival of 2 days. These experiments indicate that insufficient coating of $\mathrm{C}^{\prime}$ globulins, whether through removal of some fractions of the third component or reduction in total $\mathrm{C}^{\prime}$ available, failed to improve red cell survival.

The survival of group A I-positive normal cells labeled with ${ }^{51} \mathrm{Cr}$ was also observed in patient 
O. A. (case 3 ). $30 \%$ of the counts present at 5 min was removed at the end of $2 \mathrm{hr}$. Thereafter, the rate of removal was relatively slow but continued to be abnormal with a $t_{\frac{1}{2}}$ of 10 days. At a later date, ${ }^{51} \mathrm{Cr}$-labeled $\mathrm{C}^{\prime} 1423$-coated cells from the same donor were injected. $20 \%$ of $C^{\prime} 1423$ cells was removed at the end of the first $2 \mathrm{hr}$. Thereafter, the rate of removal approximated the removal of the normal cells. The $t_{\frac{1}{2}}$ survival was also 10 days. The ratios of liver-precordium and spleen-precordium counts during the two observations of red cell survival in case 3 are shown in Fig. 3. During the initial period of removal of the normal cells the liver-precordium ratio increased rapidly. When $C^{\prime} 1423$ cells were injected the liverprecordium ratio did not increase, a finding which suggests a different mechanism of removal.

Survival of ${ }^{51} \mathrm{Cr}$-labeled cells before and after administration of red cells from $2 U$ of blood. Previous observations had indicated discrepancies in the rate of destruction of transfused cells in case 1 . ${ }^{51} \mathrm{Cr}$-labeled normal cells had been removed rapidly with a half-life of less than $24 \mathrm{hr}$; yet red cell transfusions were given without reactions and the half-life of these cells was measured on one occa- sion by the Ashby technique to be 19 days or roughly one-third normal. This finding suggested that the mechanism for removal of normal cells by cold agglutinin was limited and that the rapid removal of ${ }^{51} \mathrm{Cr}$-labeled cells might not occur after the administration of $500 \mathrm{ml}$ of red cells.

$5 \mathrm{ml}$ of red cells was removed from each of 2 pints of group O I-positive blood within $4 \mathrm{hr}$ of withdrawal from the donors. The cells were labeled with ${ }^{51} \mathrm{Cr}$ and injected into the patient. $48 \%$ of the counts present at 5 min was removed from the circulation at $30 \mathrm{~min}$ and $52 \%$ was removed in 16 hr. During the next $6 \mathrm{hr}$, a small but significant rise in counts occurred, indicating that some sequestered cells had been returned to the circulation. An additional $5 \mathrm{ml}$ of cells was removed from each of the 2 pints of blood for ${ }^{51} \mathrm{Cr}$ labeling. The remaining cells, washed to remove $\mathrm{C}^{\prime}$, were administered without incident. After completion of the transfusion, the second suspension of ${ }^{51} \mathrm{Cr}$ labeled cells was injected. If one assumes that the ${ }^{51} \mathrm{Cr}$-labeled cells already present in the circulation were now being removed at the constant rate observed after $24 \mathrm{hr}$ in previous studies, one may calculate the survival of this second suspen-

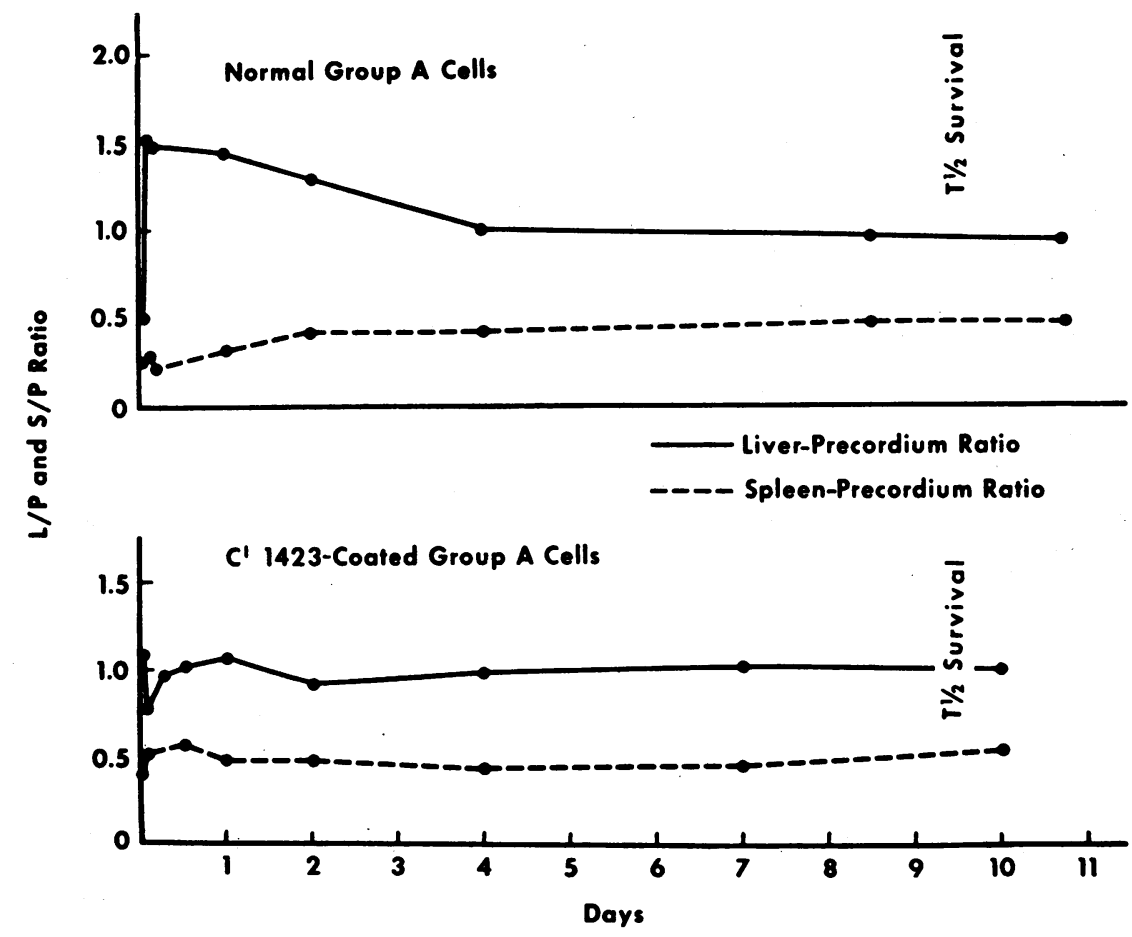

FIGURE 3 Liver-precordium and spleen-precordium ratios during the survivals of ${ }^{51} \mathrm{Cr}$ labeled normal and C'1423-coated I-positive red cells in the circulation of $\mathrm{O}$. A. 


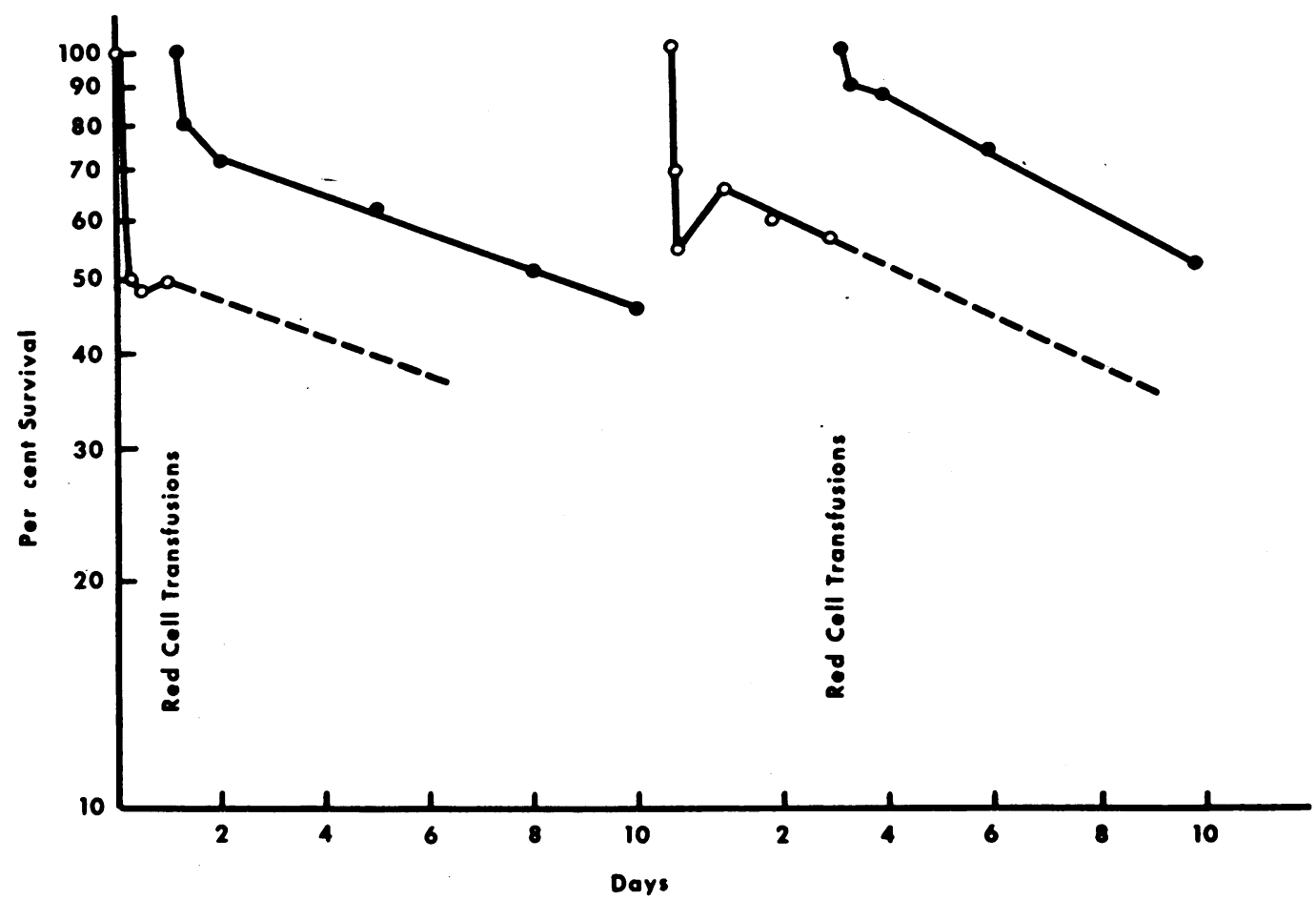

Figure 4 Survival of ${ }^{5} \mathrm{Cr}$-labeled group O I-positive cells in E. M. before and after administration of the washed red cells of 2 pints of blood from the same donors. The projected survival of the first pretransfusion infusion of ${ }^{51} \mathrm{Cr}$-labeled cells after $24 \mathrm{hr}$ is shown by the dotted line and is based on data from previous survival curves.

The observation was repeated with normal cells from other donors except that the red cell transfusions were given $72 \mathrm{hr}$ after starting the pretransfusion survival study.

sion of ${ }^{51} \mathrm{Cr}$-labeled cells given after the transfusion. $13 \%$ of the counts present at 5 min was removed at $30 \mathrm{~min}$ and $23 \%$ was removed at $16 \mathrm{hr}$. Thereafter, the rate of removal was more gradual with a $t_{z}$ of 10 days (Fig. 4).

The above observation was repeated at a later date except that the initial survival curve was observed for 3 days to record the beginning of the period of more gradual destruction after the first $24 \mathrm{hr}$ (Fig. 4). The initial rate of removal of the pretransfusion ${ }^{51} \mathrm{Cr}$-labeled cells was again rapid, with $46 \%$ removal in $1 \mathrm{hr}$ followed by a return of some cells to the circulation at the end of 24 hr. The gradual slope of red cell removal then began. After transfusion of approximately $400 \mathrm{ml}$ of red cells, the second aliquot of ${ }^{51} \mathrm{Cr}$-labeled cells was given. Initial destruction was more gradual in that $2 \%$ of the counts was removed at $40 \mathrm{~min}$ and $12 \%$ was removed at $3 \mathrm{hr}$.

Similar studies were carried out with case 2 . After completion of a survival study of group $\mathrm{O}$ I-positive cells in the patient, she received group
A I-positive cells from 2 pints of blood. A second survival study of the normal group O I-positive cells was begun promptly thereafter. As shown in Fig. 5, there was only a slight decrease in the rate of removal of group $\mathrm{O}$ cells. There was no evidence of isoimmunization to the red cells of this group $\mathrm{O}$ donor and when cells from this donor were coated with $C^{\prime}$ complex before injection they showed the improved survival depicted in Fig. 2.

A second study was carried out with group A I-positive red cells. The red cells of this donor were found in many in vitro observations to be less susceptible to $C^{\prime}$ hemolysis by cold agglutinin than the group $\mathrm{O}$ cells used in the previous observation. The rate of removal of the group A cells was less rapid (Fig. 5). After transfusion of red cells from 2 pints of blood the survival of cells from the group A I-positive donor was repeated. The initial period of rapid destruction did not occur, and the $t_{\frac{1}{2}}$ survival of 16 days was equal to that of the autologous cells.

Measurements of serum $C^{\prime}$ before and after red 


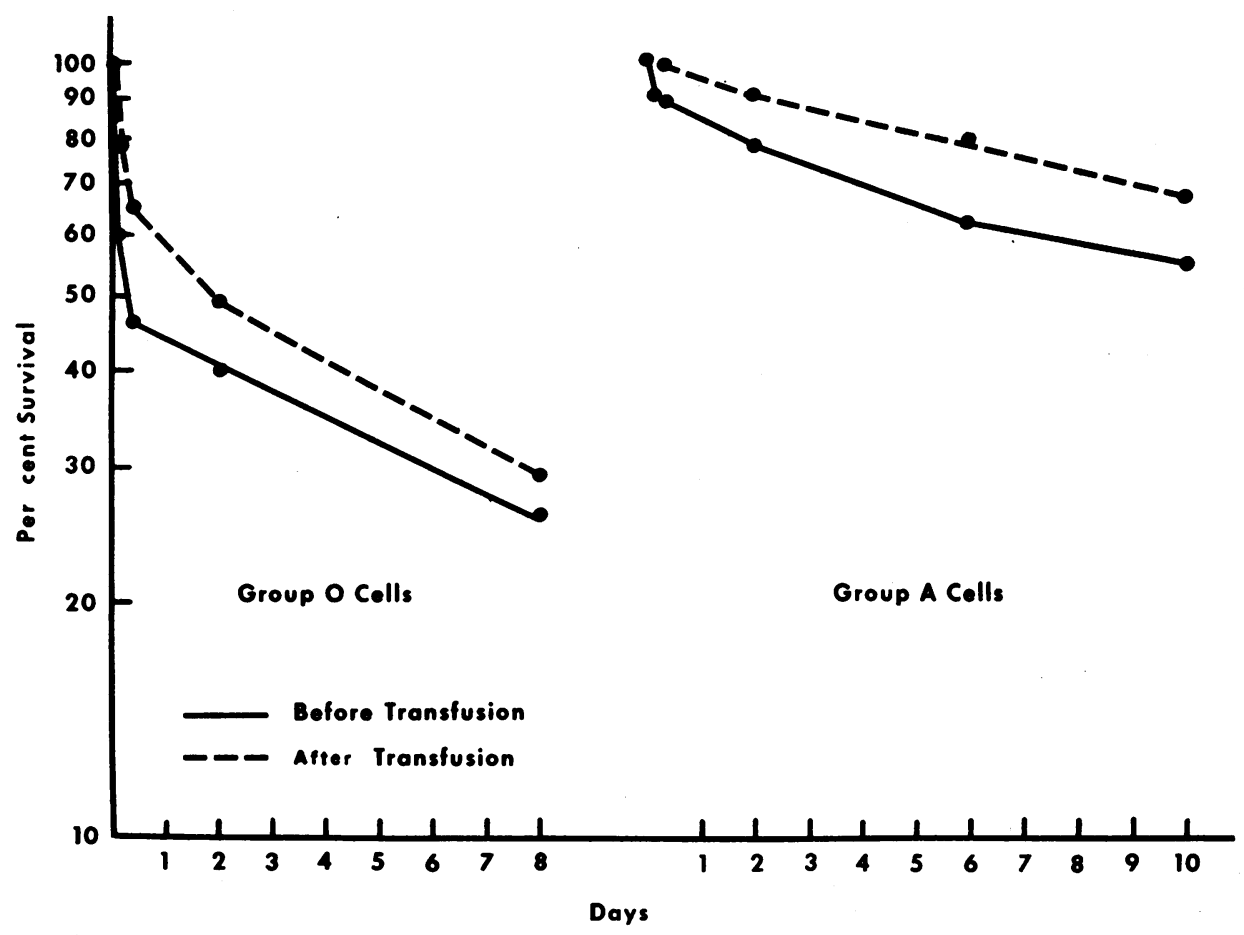

FIgURE 5 Survival of group O I-positive cells in A. J. (group A) before and after administration of $400 \mathrm{ml}$ of washed group A red cells and survival of group A I-positive cells before and after subsequent transfusion of group A cells.

cell transfusions. Serum $C^{\prime}$ levels of the patients were measured before and after the transfusions of cells from $2 \mathrm{U}$ of blood. There was significant reduction in the depressed levels of serum $\mathrm{C}^{\prime}$, as shown in Tables III and IV. This reduction can be attributed to the adsorption of $C^{\prime}$ globulins to the red cells by action of the cold agglutinin. Before

\section{TABLE III}

Effect of Transfusing $400 \mathrm{ml}$ of Washed Red Cells on Serum $C^{\prime}$ Levels in E. M.*

\begin{tabular}{|c|c|c|c|c|}
\hline \multirow{2}{*}{ Time } & \multicolumn{2}{|c|}{ Patient } & \multicolumn{2}{|c|}{ Control } \\
\hline & $\mathrm{C}^{\prime} \mathrm{H} 100$ & $\mathrm{C}^{\prime} \mathrm{H} 50$ & $\mathrm{C}^{\prime} \mathrm{H} 100$ & $\mathrm{C}^{\prime} \mathrm{H} 50$ \\
\hline \multirow{2}{*}{\multicolumn{5}{|c|}{$\begin{array}{l}h r \\
\text { Pretransfusion }\end{array}$}} \\
\hline & & & & \\
\hline 24 & 20 & 89 & \multirow{3}{*}{49} & \multirow{3}{*}{139} \\
\hline & & & & \\
\hline 0 & 19 & 82 & & \\
\hline \multicolumn{5}{|c|}{ Posttransfusion } \\
\hline 0.1 & 0 & 60 & & \\
\hline 0.5 & 0 & 50 & 42 & 127 \\
\hline 24 & 0 & 78 & & \\
\hline
\end{tabular}

transfusion, all of the circulating cells were agglutinated in anti- $\beta$-globulin serum. After transfusion, a high proportion of cells was not agglutinated; this indicated a lack of $\beta$-globulin $\left(\mathrm{C}^{\prime}\right)$ coating. $24 \mathrm{hr}$ later the agglutination of the circu-

\section{TABLE IV}

Effect of Transfusing $400 \mathrm{ml}$ of Washed Red Cells on Serum $C^{\prime}$ Levels in $A$. J.

\begin{tabular}{cccccc}
\hline & \multicolumn{2}{c}{ Patient } & & \multicolumn{2}{c}{ Control } \\
\cline { 6 - 6 } \cline { 5 - 6 } Time & $C^{\prime}$ H100 & $C^{\prime}$ H50 & & $C^{\prime}$ H100 & $C^{\prime}$ H50 \\
\hline $\begin{array}{c}h r \\
\text { Pretransfusion }\end{array}$ & 15 & 33 & & 61 & 124 \\
$\begin{array}{c}\text { Posttransfusion } \\
0.5\end{array}$ & 0 & 0 & & 61 & 124 \\
96 & 0 & 10 & & & \\
288 & 8 & 25 & & 62 & 123 \\
& & & & & \\
Pretransfusion & 15 & 24 & & 58 & 109 \\
Posttransfusion & & & & & \\
0.1 & 0 & 0 & & 68 & 110 \\
24 & 0 & 0.6 & & \\
268 & 0 & 5 & & 60 & 114 \\
480 & 11 & 33 & & 58 & 119 \\
\hline
\end{tabular}

* Recorded in 100 and $50 \%$ hemolytic units. 
TABLE V

Susceptibility to Complement Hemolysis by Cold Agglutinin of Normal Group A I-Positive Cells Labeled with ${ }^{51} \mathrm{Cr}$ during Survival in the Circulation of $A . J$.

\begin{tabular}{cccc}
\hline & $\begin{array}{c}\text { Hemolysis } \\
\text { s1Cr- } \\
\text { labeled } \\
\text { cell } \\
\text { survival }\end{array}$ & $\begin{array}{c}\text { Hemolysis } \\
\text { of } 51 \mathrm{Cr}- \\
\text { cell samples } \\
\text { at } 25^{\circ} \mathrm{C}, \\
\text { pH } 6.8\end{array}$ & $\begin{array}{c}\text { cells in } \\
\text { sample at } \\
25^{\circ} \mathrm{C} \text {, } \\
\text { pH } 6.8\end{array}$ \\
\hline Time & $\%$ & $\%$ & $\%$ \\
0.1 & 100 & 5 & 53 \\
0.5 & 90 & 5 & 49 \\
1 & 88 & 5 & 45 \\
3 & 84 & 5 & 43 \\
24 & 72 & 3 & 17 \\
72 & 61 & 3 & 12 \\
144 & 54 & 3 & 6 \\
\hline
\end{tabular}

lating cells in anti- $\beta$-globulin serum was again complete.

Levels of serum $\mathrm{C}^{\prime}$ were measured before and after transfusions of red cells in 10 patients with a variety of hematologic disorders. Change in $\mathrm{C}^{\prime} \mathrm{H} 50$ units varied between +3 and $-14 \%$ with an average change of $-3 \%$.

Development of resistance to hemolysis of ${ }^{51} \mathrm{Cr}$ labeled cells in vivo. The susceptibility of ${ }^{51} \mathrm{Cr}$ labeled group A I-positive red cells to complement hemolysis after their introduction into the circulation of case 2 was studied by determining the percentage hemolysis of the ${ }^{51} \mathrm{Cr}$-labeled cells compared with the hemolysis of samples of the total cell population.

$4 \mathrm{ml}$ of red cells of a normal group A donor was labeled with ${ }^{51} \mathrm{Cr}$ and transfused into the patient. The time of withdrawal of the sample, the per cent hemolysis of the cell suspension, and the per cent hemolysis of the ${ }^{51} \mathrm{Cr}$-labeled cells are presented in Table V. The ${ }^{51} \mathrm{Cr}$-labeled cells were susceptible to $C^{\prime}$ hemolysis by cold agglutinin after injection, but acquired resistance during the first few hours. After $24 \mathrm{hr}$ the hemolysis of the transfused group A I-positive cells had decreased from 53 to $17 \%$, even though $72 \%$ of the labeled red cells remained in the circulation. The $\mathrm{pH}$ of 6.8 and temperature of $25^{\circ} \mathrm{C}$ were selected in order to produce maximum hemolysis of the patient's cells as well as of the injected ${ }^{51} \mathrm{Cr}$-labeled cells. These observations were repeated at a later date with similar results.

\section{DISCUSSION}

Consistent with observations of others, the red cells of the four patients with chronic hemolytic anemia due to cold agglutinins were agglutinated by antisera containing anti- $\beta_{1 \mathrm{c}}$ - or anti- $\beta_{1 \mathrm{e}}$-activity $(4,5)$. There is evidence that the intensity of agglutination in anti- $\beta$-globulin serum and the adsorption of ${ }^{131} \mathrm{I}$-labeled anti- $\beta$-globulin serum was related to the amount of $C^{\prime}$ globulin accumulated on the red cell surface (2). Normal I-positive red cells, incubated with cold agglutinin and $C^{\prime}$ for several hours, adsorbed ${ }^{131}$ I-labeled anti- $\beta$-globulin serum with the same avidity as the circulating cells of the patients. The resistance to $C^{\prime}$ hemolysis increased as $C^{\prime}$ complex accumulated.

The accumulation of $C^{\prime}$ globulins by the patient's cells was consistent with the demonstration that the cold agglutinins of all four patients had a thermal range of activity sufficient to cause attachment of $C^{\prime}$ globulins to red cells during incubation at $37^{\circ} \mathrm{C}$. Several other observations indicated that $\mathrm{C}^{\prime}$ fixation by cold agglutinins occurred in the circulation at normal body temperature. An abrupt drop in serum $C^{\prime}$ level invariably followed the infusion of large volumes of red cells into two of the patients. In addition, there was evidence that the reaction with $C^{\prime}$ continued for some time after transfusion since it was several hours before all of the circulating red cells were again agglutinated by anti- $\beta$-globulin serum. Further evidence for gradual accumulation of $\mathrm{C}^{\prime}$ globulins in vivo was demonstrated in the development of resistance by the transfused red cells to $\mathrm{C}^{\prime}$ hemolysis by cold agglutinin (Table V). The normal ${ }^{51} \mathrm{Cr}$-labeled cells acquired considerable resistance to $\mathrm{C}^{\prime}$ hemolysis during the first $24 \mathrm{hr}$ and continued to do so for several days.

Several lines of evidence indicate that the acquisition of $\mathrm{C}^{\prime}$ coating affected the rate and route of destruction of red cells in the patients' circulation. The red cells of the four patients that were labeled with ${ }^{51} \mathrm{Cr}$ and returned to the circulation were removed at an exponential rate. The red cells of two patients, A. J. and B. C., were observed to have a normal survival time in the circulation of normal and asplenic subjects. It is evident that the red cells of these patients, although coated with $\mathrm{C}^{\prime}$ globulins, were not irreversibly damaged and required continuing action by cold agglutinin and $\mathrm{C}^{\prime}$ to produce accelerated destruction. Only the 
red cells of E. M. were removed from the circulation of normal subjects at an accelerated rate. His red cells had developed a marked spherocytosis after splenectomy, suggesting that red cells which would have been removed by the spleen were allowed to remain in the circulation. The splenic filter mechanism has been shown to be particularly effective in removing spherocytic cells from the circulation in a variety of hemolytic states (10-12).

The injection of normal red cells into the circulation of the three patients with chronic hemolytic anemia resulted in an initial phase of rapid removal followed by a second phase of more gradual destruction. The slope of the survival curve during the second phase was exponential and approximated the rate of removal of autologous red cells. The slower second phase of abnormal destruction was associated with the accumulation of $\mathrm{C}^{\prime}$ complexes and the acquisition of resistance to $\mathrm{C}^{\prime}$ hemolysis by the surviving red cells. Coating normal red cells from the same donor with $\mathrm{C}^{\prime}$ complex by interaction with cold agglutinin and $\mathrm{C}^{\prime}$ in vitro before injection produced slight to marked improvement in the survival during the first few hours. The disappearance was then exponential and also resembled the survival of autologous red cells. It appears from these data that red cells can be partially protected from the initial rapid phase of abnormal destruction in vivo by a coating of $\mathrm{C}^{\prime}$ complex. Since all three patients had been transfused before our studies, it is possible that isoantibodies for red cells influenced the survival curves. It has been demonstrated that small quantities of ${ }^{51} \mathrm{Cr}$-labeled cells may be eliminated rapidly by isoantibodies that cannot be detected in vitro by available serological techniques (13). In some instances of suspected isoimmunization a second injection of red cells from the same donor resulted in a normal survival; therefore, the improved survival of the C'1423-coated cells after the injection of normal cells does not entirely eliminate the possibility of isoimmunization (14). However, it was demonstrated that a repeat injection of the normal red cells into A. J. after the improved survival of the C'1423-coated cells resulted in a typical biphasic curve of disappearance identical to the first survival curve. Furthermore, in separate observations with $E$. $M$. and $A$. J. administration of C'1423-coated cells before administration of normal red cells also resulted in improved survival of the $C^{\prime} 1423$ cells. The removal of normal ${ }^{51} \mathrm{Cr}$ labeled cells from different donors all followed a biphasic pattern which has been observed with some isoantibodies, most of which utilize $C^{\prime}(10)$. Differences in rate of removal could be correlated with the amount of I antigen (Fig. 5), and the second phase of slower removal of normal red cells which had become coated with $C^{\prime}$ approximated that of the patient's cells, suggesting that the same mechanism of removal was responsible.

It is of interest that red cells coated with $C^{\prime} 1423$ complex without acquiring resistance to $C^{\prime}$ hemolysis in vitro because of the reduced amounts of $C^{\prime}$ used in preparation were removed from the circulation almost as rapidly as normal red cells. It is not clear why coating with $\mathrm{C}^{\prime}$ globulins by $\mathrm{R} 3$ serum failed to produce significant protection in vivo even though $\mathrm{C}^{\prime}$ hemolysis in vitro was inhibited.

$\mathrm{C}^{\prime}$ coating by cold agglutinin also influences the site of removal of red cells. In all three patients who received normal cells, counts accumulated in the liver during the initial rapid phase of removal of cells from the circulation. This finding is consistent with the concept that the normal red cells were susceptible to acute $\mathrm{C}^{\prime}$ damage in vivo. $\mathrm{Ob}$ servations by Jandl and Kaplan (12) and by Cutbush and Mollison (10) have previously shown that cells subjected to sufficient damage by other $\mathrm{C}^{\prime}$-fixing red cell antibodies were removed at a rapid rate and principally by the liver.

Normal red cells that survived the acute phase of rapid destruction were then removed at a slower rate without predominance of either the liver or the spleen. The autologous red cells of cases 2 and 3 also failed to accumulate predominantly in either the liver or the spleen, which is in keeping with the observation of Lewis, Szur, and Dacie (15). Only in the fourth patient, B. C., was there unequivocal evidence of splenic accumulation of autologous cells. It may be significant that the red cells of this patient had the shortest survival time with a $t_{1}$ of 7 days. Failure of organ accumulation of radioactivity in the other two patients may have been due to the less rapid rate of abnormal destruction so that accumulation of radioactivity from red cell destruction could have been balanced by loss of ${ }^{51} \mathrm{Cr}$ by the organs (9).

The survival studies of normal red cells before and after transfusions in E. M. and A. J. indicate that the mechanism that removed cells rapidly had 
limitations and could be partially overwhelmed by large volumes of red cells. The fall in serum $C^{\prime}$ levels which followed the introduction of large volumes of red cells is the most obvious explanation of this partial suppression of the removal mechanism, since there was no reduction in cold agglutinin titer. Adsorption of an isoantibody by the large amount of transfused cells may be postulated to be a mechanism of improved survival of the second injection of ${ }^{51} \mathrm{Cr}$-labeled cells. Such a mechanism should have allowed a normal survival initially followed by rapid destruction as antibody reappeared, which is the opposite of what was observed. Temporary saturation of the reticuloendothelial tissue might have been a factor in the improved survival of labeled cells after transfusion. If this were the major factor, however, destruction of the damaged cells should have continued as reticuloendothelial tissue recovered. The survival curves in case 2 (Fig. 5), particularly those with group A cells, suggested that no such suppression had occurred.

The destruction of red cells by cold agglutinins appears to be dependent on several variables, including the thermal range of the cold agglutinin, its $C^{\prime}$ fixing activity, the susceptibility of the red cells to $C^{\prime}$ damage, and the levels of serum $C^{\prime}$. The syndrome presented by the four patients described in this report can occur if the cold agglutinins react with red cells at normal body temperature. The circulating red cells become coated with $\mathrm{C}^{\prime}$ globulins and though still susceptible to agglutination by cold agglutinins are relatively resistant to acute damage by $C^{\prime}$. Such patients have acrocyanosis from intravascular agglutination when chilled but may escape acute exacerbations of hemolysis. This mechanism appears insufficient to prevent intravascular hemolysis in all patients after they are chilled, since episodes of hemoglobinuria have been reported to occur in some (16, 17).

\section{ACKNOWLEDGMENT}

This study was supported by a grant-in-aid from the U. S. Public Health Service, Project No. A-548, C16.

\section{REFERENCES}

1. Evans, R. S., E. Turner, and M. Bingham. 1965. Studies with radioiodinated cold agglutinins of ten patients. Am. J. Med. 38: 378.

2. Evans, R. S., E. Turner, and M. Bingham. 1967. Chronic hemolytic anemia due to cold agglutinins.
The mechanism of resistance of red cells to $C^{\prime}$ hemolysis by cold agglutinins. J. Clin. Invest. 46: 1461.

3. Evans, R. S., M. Bingham, and E. Turner. 1965. Autoimmune hemolytic disease: observations of serological reactions and disease activity. Ann. N. Y. Acad. Sci. 124: 422.

4. Dacie, J. V., J. H. Crookston, and W. N. Christenson. 1957. "Incomplete" cold antibodies. Role of complement in sensitization to antiglobulin serum by potentially haemolytic antibodies. Brit. J. Haematol. 3: 77.

5. Harboe, M., H. J. Müller-Eberhard, H. Fudenberg, M. J. Polley, and P. L. Mollison. 1963. Identification of the components of complement participating in the antiglobulin reaction. Immunology. 6: 412.

6. Ecker, E. E., L. Pillemer, and S. Seifter. 1943. Immunochemical studies on human serum. I. Human complement and its components. J. Immunol. 47: 181.

7. Cooper, M., and C. A. Owen, Jr. 1956. Labeling human erythrocytes with radiochromium. J. Lab. Clin. Med. 47: 65.

8. Donohue, D. M., A. G. Motulsky, E. R. Giblett, G. Pirzio-Biroli, V. Viranuvatti, and C. A. Finch. 1955. The use of chromium as a red cell tag. Brit. J. Haematol. 1: 249.

9. Jandl, J. H., M. S. Greenberg, R. H. Yonemoto, and W. B. Castle. 1956. Clinical determination of the sites of red cell sequestration in haemolytic anemias. $J$. Clin. Invest. 35: 842.

10. Cutbush, M., and P. L. Mollison. 1958. Relation between characteristics of blood-group antibodies in vitro and associated patterns of red-cell destruction in vivo. Brit. J. Haematol. 4: 115.

11. Jones, N. C., P. L. Mollison, and N. Veall. 1957. Removal of incompatible red cells by the spleen. Brit. J. Haematol. 3: 125.

12. Jandl, J. H., and M. E. Kaplan. 1960. The destruction of red cells by antibodies in man. III. Quantitative factors influencing the patterns of hemolysis in vivo. J. Clin. Invest. 39: 1145.

13. Jandl, J. H., and M. S. Greenberg. 1957. The selective destruction of transfused "compatible" normal red cells in two patients with splenomegaly. J. Lab. Clin. Med. 49: 233

14. Adner, P. L., S. Foconi, and S. Sjölin. 1963. Immunization after intravenous injection of small amounts of ${ }^{5} \mathrm{Cr}$-labelled red cells. Brit. J. Haematol. 9: 288.

15. Lewis, S. M., L. Szur, and J. V. Dacie. 1960. The pattern of erythrocyte destruction in haemolytic anaemia, as studied with radioactive chromium. Brit. $J$. Haematol. 6: 122.

16. Ferriman, D. G., J. V. Dacie, K. D. Keele, and J. M. Fullerton. 1951 The association of Raynaud's phenomena, chronic haemolytic anaemia, and the formation of cold antibodies. Quart. J. Med. 20: 275.

17. Dacie, J. V. 1962. The Haemolytic Anaemias, Congenital and Acquired. Part II. The Auto-immune Haemolytic Anaemias. Grune and Stratton, New York. 2nd edition. 482. 